\title{
On the feeding of copepods on Thalassiosira partheneia from the Northwest African upwelling area
}

\author{
Sigrid B. Schnack* \\ Institut für Meereskunde, Düsternbrooker Weg 20, D-2300 Kiel, Federal Republic of Germany
}

\begin{abstract}
Copepod feeding on the colony-building diatom Thalassiosira partheneia was studied in spring 1975 in the Northwest African upwelling area. Healthy, whole colonies of $T$. partheneia (diameter $\sim 1 \mathrm{~cm}$ ) were offered as food as well as single cells (diameter $\sim 9 \mu \mathrm{m}$ ) after disintegration of the colonies. In addition, comparative experiments were carried out with the dinoflagellate Scrippsiella trochoidea. None of the 13 copepod species studied was able to feed on the entire colony. However, feeding on single cells after disintegration of the colonies was found for 4 copepod species studied. The actual quantity of food intake ranged from 14.7 to $124.0 \%$ body carbon per day. The lowest values were obtained for Calanus helgolandicus, the highest for Temora stylifera.
\end{abstract}

\section{INTRODUCTION}

Thalassiosira partheneia Schrader, a small centric diatom $(\sim 9 \mu \mathrm{m}$ diameter), is the most striking phytoplankton species in the Northwest African upwelling area. This alga forms colonies of sizes up to $5 \mathrm{~cm}$ in length and up to $1 \mathrm{~cm}$ in diameter, each with several hundred up to 25,000 cells (Elbrächter and Boje, 1978). So far, little is known about the possible role of $T$. partheneia as a food source for zooplankton. Small protozoans such as heterotrophic dinoflagellates, ciliates and amoebae live within healthy colonies and seem to feed on single cells (Elbrächter and Boje, 1978). T. partheneia also seems to be a food source for filter-feeders but only after disintegration into short chains and single cells. This disintegration, shown in culture experiments, can be due to senescence and damage due to excess light (Elbrächter and Boje, 1978). According to Elbrächter (pers. comm.) it is unlikely that colonies are destroyed by large grazers or by turbulence under culture conditions. At 60 to $75 \mathrm{~m}$ water depth, Elbrächter and Boje (1978) observed mainly single cells up to $130,000 \mathrm{I}^{-1}$.

During a cruise of R. V. 'Meteor' in spring 1975 to the Northwest African upwelling area, the role of Thalas-

\footnotetext{
- Present address: Alfred-Wegener-Institut für Polarforschung, Columbus-Center, D-2850 Bremerhaven, Federal Republic of Germany
}

siosira partheneia as a possible food source for copepods was investigated. The question addressed was: are copepods able to take advantage of the mass distribution of this alga and, if so, in what form does this occur, i.e. can copepods utilize the big colonies and/or do they only feed on $T$. partheneia after disintegration into single cells? Comparative studies were carried out using the dinoflagellate Scrippsiella trochoidea (Stein) Loeblich III as food supply.

\section{MATERIAL AND METHODS}

Copepods used in experiments were collected in the upper $60 \mathrm{~m}$ with a Helgoländer Larvae net of $300 \mu \mathrm{m}$ mesh size during a 'Thalassiosira partheneia'-project

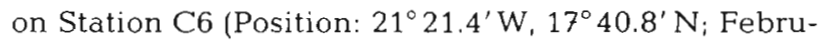
ary 8,1975$)$. Hauls were taken at night. Only healthy animals were used for experiments.

Thalassiosira partheneia was sampled at daytime by bucket from the surface of the same sampling site. Colonies visible by naked eye were picked out by pipette and transferred into 1-l glass jars filled with $0.2 \mu \mathrm{m}$ filtered seawater. To obtain single cells of $T$. partheneia, colonies collected $10 \mathrm{~d}$ before the experiments at the same station were exposed to intense light $\left(40 \mu \mathrm{E} \mathrm{m}^{-2} \mathrm{~s}^{-1}\right)$ without changing the medium. The condition of the algae was checked every day under a stereomicroscope. 
Scrippsiella trochoidea was prepared from cultures cultivated by Elbrächter (Clone BAH ME 64).

Ten to 20 adults were placed in 2 I of filtered seawater. After $1 \mathrm{~d}$, the respective algal suspension was added to the beakers and the copepods were prefed for 20 to $24 \mathrm{~h}$. During preconditioning, food levels were the same as in the experiments. Each experimental set included at least 1 control beaker (i.e. without copepods). No rotation of the beakers was possible, but the motion of the ship helped to keep the algae in suspension as regular checks demonstrated. Particle concentration in experiments with single cells of Thalassiosira partheneia and with Scrippsiella trochoidea was checked on board with a Coulter Counter Channelyzer Model $Z_{B}$. At the beginning and end of each experiment, 6 subsamples of $100 \mathrm{ml}$ each from different parts of the beakers ( 2 from the surface, 2 from the middle, 2 from the bottom) were preserved with formalin (end concentration: $2 \%$ ) and counted with an inverted microscope at a magnification of $400 \times / T$. partheneia) and of $250 \times$ (S. trochoidea). At least 200 cells were counted from each subsample. The relative coefficient of variation between the subsamples was low for all experiments $\left(\mathrm{V}_{\mathrm{r}}<4.9 \%\right)$. Average cell volume and carbon content of the algae were estimated after Smetacek (1975). Experiments were run in dim light for 8 to $10 \mathrm{~h}$ at $15^{\circ} \mathrm{C}$. In situ temperatures in the upper $60 \mathrm{~m}$ at Station $\mathrm{C} 6$ ranged from $15^{\circ}$ to $17^{\circ} \mathrm{C}$ (Brockmann et al., 1977). Filtration and ingestion rates were calculated after Frost (1972).

For studies on the possible feeding on colonies of Thalassiosira partheneia, 13 different copepod species were used (Table 1). In the 81 experiments conducted, the algae were labelled with radioactive carbon $\left({ }^{14} \mathrm{C}\right)$ or phosphorus $\left({ }^{32} \mathrm{P}\right)$ for 1 to $3 \mathrm{~d}$ and then supplied as food. Only colonies of similar length $(1.5$ to $2.0 \mathrm{~cm})$

Table 1. Copepod species used in experiments with colonies of Thalassiosira partheneia, separated according to their feeding behaviour

\begin{tabular}{|c|c|c|}
\hline Copepod species & $\begin{array}{l}\text { Cephalothorax } \\
\text { length }(\mathrm{mm})\end{array}$ & $\begin{array}{c}\text { Feeding } \\
\text { behaviour }\end{array}$ \\
\hline Calanoides carinatus, $q$ & 2.3 & Filtration \\
\hline Calanus helgolandicus, $q$ & 2.2 & Filtration \\
\hline Rhincalanus nasutus, $?$ & 4.4 & Filtration \\
\hline Eucalanus crassus, 9 & 2.9 & Filtration \\
\hline Acartia clausi, 9 & 0.9 & Mixed \\
\hline Centropages chierchiae, $f$ & 1.4 & Mixed \\
\hline Centropages chierchiae, o & 1.2 & Mixed \\
\hline Temora stylifera, 9 & 1.2 & Mixed \\
\hline Temora stylifera, $\delta$ & 1.0 & Mixed \\
\hline Anomalocera patersoni, 9 & 3.0 & Grasping \\
\hline Candacia armata, 9 & 1.9 & Grasping \\
\hline Oncaea conifera, 9 & -0.5 & Grasping \\
\hline Corycaeus sp. & 1.0 & Grasping \\
\hline
\end{tabular}

were used; the length was measured at the beginning and end of each experiment. Experiments were run for 7 to $48 \mathrm{~h}$. During that time, the colonies were buoyant; this was checked several times. Radioactivity in water and colonies was measured at the beginning and end of the experiments. Copepods were removed after experiments, sorted into scintillation vials and counted in a liquid scintillation counter.

\section{RESULTS}

Table 1 lists the 13 different copepod species used as potential consumers of healthy colonies of Thalassiosira partheneia. None of the copepod species, in spite of the various feeding modes represented, fed on the colonies, i.e. became radioactive, and no faecal pellets were produced.

To find out whether copepods can utilize the single cells of Thalassiosira partheneia (single cell: $9 \times 4 \mu \mathrm{m}$, $18 \mathrm{pgC}$ ), experiments were conducted with 6 different copepod species (Calanoides carinatus, Calanus helgolandicus, Centropages chierchiae, Temora stylifera, Candacia armata, Oncaea conifera). No feeding could be ascertained in the case of the 2 raptorial species, $C$. armata and $O$. conifera, but the other 4 species did indeed feed on $T$. partheneia as shown in Figs. 1 to 4. The figures include the results obtained from feeding experiments using Scrippsiella trochoidea $(20 \mu \mathrm{m}, 390$ $\mathrm{pgC}$ ) as food source. Initial phytoplankton carbon concentration ranged between 4 and $99 \mu \mathrm{gC} 1^{-1}$ for $S$.

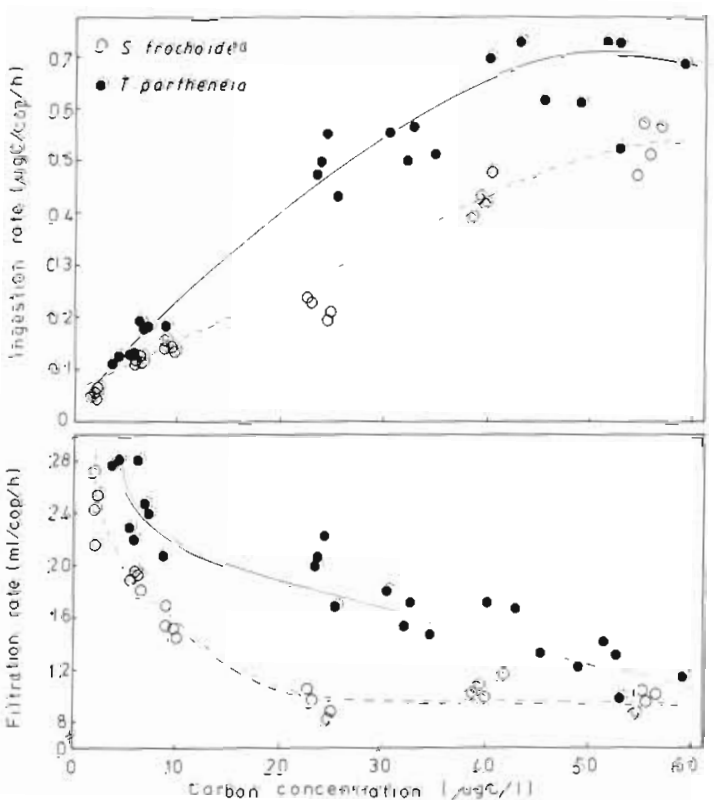

Fig. 1. Calanoides carinatus. Filtration rate and ingestion rate on single cells of Thalassiosira partheneia (solid line) and Scrippsiella trochoidea (broken line) plotted against mean food concentration 


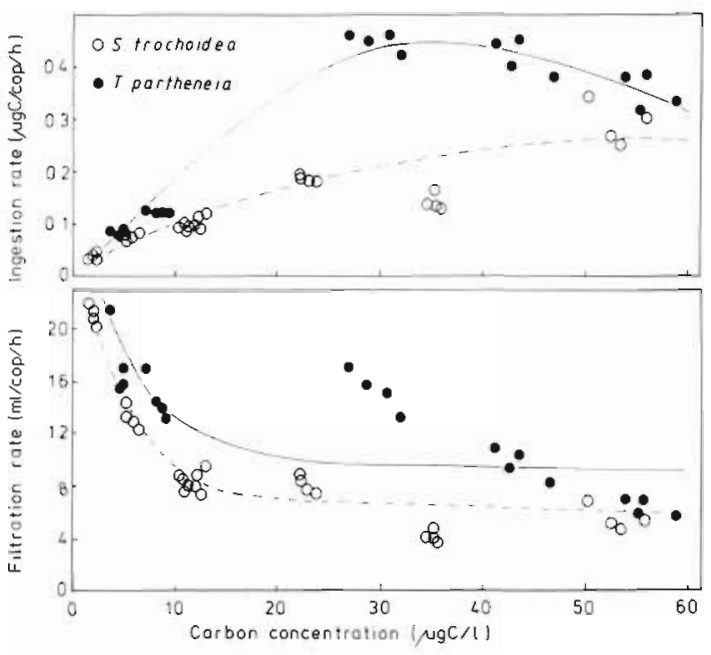

Fig. 2. Calanus helgolandicus. Filtration rate and ingestion rate on single cells of Thalassiosira partheneia (solid line) and Scrippsiella trochoidea (broken line) plotted against mean food concentration

trochoidea and between 9 and $84 \mu \mathrm{gC}^{-1}$ for singlecell $T$. partheneia.

The 2 filter-feeding species, Calanoides carinatus and Calanus helgolandicus, showed higher filtration rates on the smaller Thalassiosira partheneia (Figs. 1 and 2); the 2 mixed-mode species, on Scrippsiella trochoidea (Figs. 3 and 4). Filtration rates were in any case higher at low food concentrations, decreasing with increasing food densities.

The quantity of food ingested and the maximum rations are summarized in Table 2. Dry-weight of deep-frozen copepods was determined and converted to carbon after Lenz (1974). The amount eaten per individual per day is expressed as percentage of carbon content of the copepods. The difference obtained for both phytoplankton species offered as food is relatively low in Calanoides carinatus and Calanus helgolandicus, compared with Temora stylifera and Centropages chierchiae, which ingested Scrippsiella

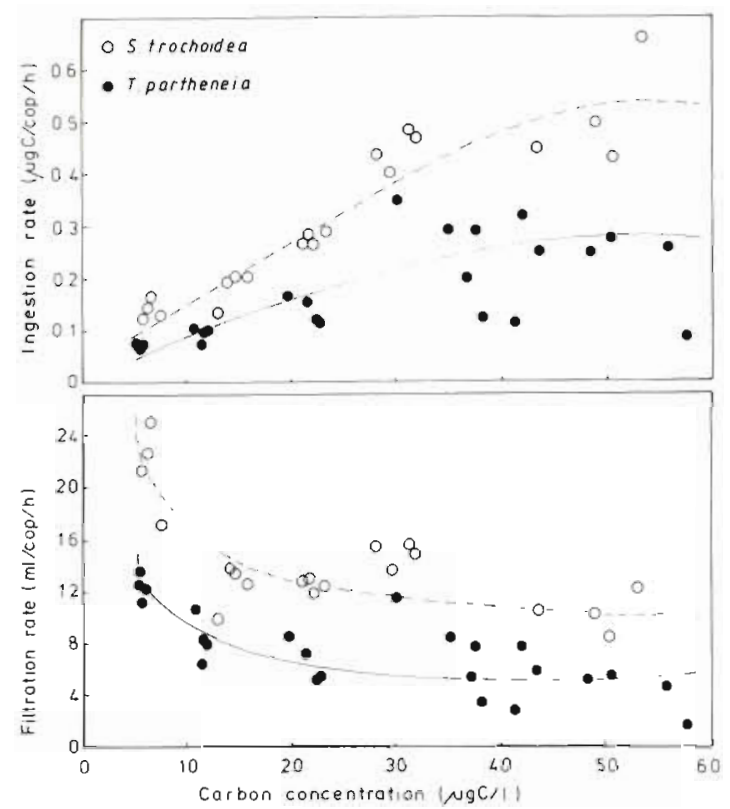

Fig. 3. Centropages chierchiae. Filtration rate and ingestion rate on single cells of Thalassiosira partheneia (solid line) and Scrippsiella trochoidea (broken line) plotted against mean food concentration

trochoidea more efficiently than Thalassiosira partheneia (1.5 and 1.9 times, respectively).

\section{DISCUSSION}

The average value for food intake is about 40 to $60 \%$ of body weight per day for late copepodids and adult copepods (Parsons et al., 1977). The food intake expressed as percentage of body carbon was below this average value in experiments with Calanoides carinatus and Calanus helgolandicus feeding on both algal species and with Centropages chierchiae feeding on Thalassiosira partheneia. Under experimental conditions, Temora stylifera consumed a quantity of food

Table 2. Quantity of food ingested

\begin{tabular}{|c|c|c|c|c|c|}
\hline \multirow[b]{2}{*}{ Copepod species } & \multirow[b]{2}{*}{ Algae species } & \multicolumn{2}{|c|}{ Food density } & \multirow{2}{*}{$\begin{array}{c}\text { Max. ration } \\
\text { obtained } \\
\left(\mu \mathrm{g} \mathrm{C} \operatorname{cop}^{-1} \mathrm{~d}^{-1}\right)\end{array}$} & \multirow{2}{*}{$\begin{array}{l}\text { Max. ration } \\
\left(\% \text { body } \mathrm{C} \mathrm{d}^{-1}\right)\end{array}$} \\
\hline & & $\begin{array}{l}\text { Min. } \\
\qquad(\mu \mathrm{s}\end{array}$ & Max. & & \\
\hline \multirow{2}{*}{$\begin{array}{l}\text { Calanoides } \\
\text { carinatus }\end{array}$} & T. partheneia & 4.1 & 59.6 & 17.63 & 29.38 \\
\hline & S. trochoidea & 2.0 & 56.5 & 13.66 & 22.77 \\
\hline \multirow{2}{*}{$\begin{array}{l}\text { Calanus } \\
\text { helgolandicus }\end{array}$} & T. partheneia & 3.9 & 58.8 & 10.99 & 19.63 \\
\hline & S. trochoidea & 1.8 & 55.9 & 8.21 & 14.66 \\
\hline \multirow{2}{*}{$\begin{array}{l}\text { Centropages } \\
\text { chierchiae }\end{array}$} & $T$ partheneia & 5.2 & 57.4 & 8.22 & 29.36 \\
\hline & S. trochoidea & 5.7 & 53.2 & 15.68 & 56.00 \\
\hline \multirow{2}{*}{$\begin{array}{l}\text { Temora } \\
\text { stylifera }\end{array}$} & T. partheneia & 4.4 & 53.1 & 11.04 & 78.86 \\
\hline & S. trochoided & 4.4 & 58.5 & 17.36 & 124.00 \\
\hline
\end{tabular}




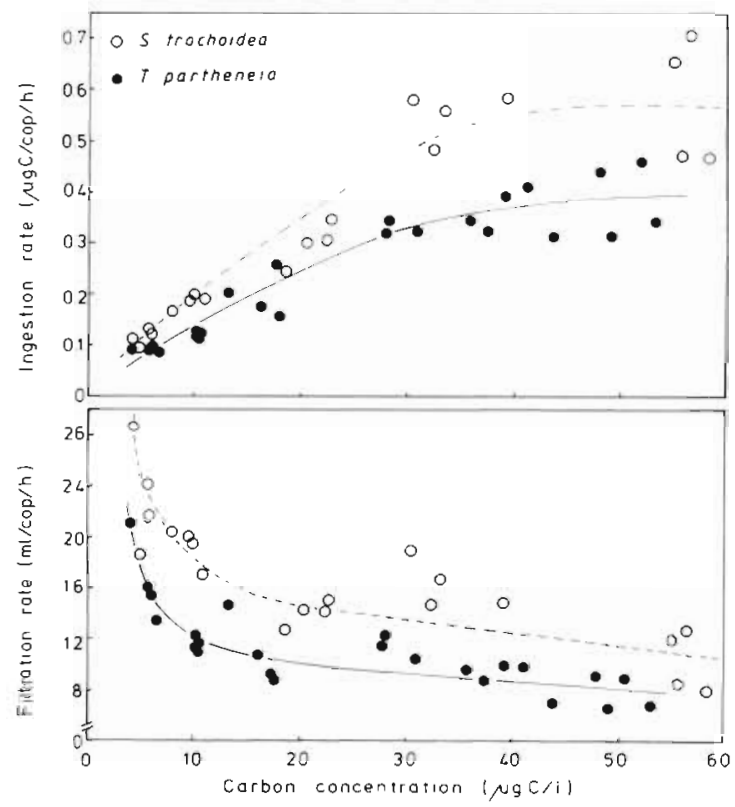

Fig. 4. Temora stylifera. Filtration rate and ingestion rate on single cells of Thalassiosira partheneia (solid line) and Scrippsiella trochoidea (broken line) plotted against mean food concentration

equivalent to a greater proportion of its body weight than the 3 other species. Similar observations for another Temora species ( $T$. longicornis) were reported by Marshall and Orr (1966) and Poulet (1978).

It appears that the copepods are not able to feed on healthy, whole colonies of Thalassiosira partheneia. Nevertheless, single cells, after disintegration, are ingested by copepods. The high filtration rates on individual cells of $T$. partheneia are contrary to those reported by Conover (1956) and Mullin (1963), in which decreasing filtration rates with senescent phytoplankton cultures as food supply were observed. It is even more remarkable that Calanoides carinatus and Calanus helgolandicus grazed less efficiently on cultures of the larger dinoflagellate Scrippsiella trochoidea in good physiological state than on single celled $T$. partheneia at comparable food concentrations.

Considerable discussion has focused on the feeding response of zooplankton at very low food concentrations (e.g. Parsons et al., 1967; Frost, 1975; Muck and Lampert, 1980). Frost's (1975) results indicate that there was an interrelationship between food size and the concentration at which feeding rates decreased; large phytoplankton cells were grazed more efficiently at low food levels than smaller ones. Frost (1975) calculated from earlier data, threshold concentrations for Calanus pacificus varying between 95 and $13 \mu \mathrm{gC}^{-1}$, depending on the different sizes (diameters between 11 and $87 \mu \mathrm{m}$ ) of single centric diatoms offered.
Schnack (in prep.) described for the copepods $\mathrm{Ca}$ lanoides carinatus and Centropages chierchiae zero feeding below $0.9 \mu \mathrm{gC}^{-1}$ when offered the centric diatom Thalassiosira eccentrica, whereas feeding was observed at the same food concentration when the motile dinoflagellate Gymnodinium splendens was offered.

Average phytoplankton and protozooplankton carbon (PPC/PZPC) concentration in the upper $75 \mathrm{~m}$ at Station $\mathrm{C} 6$ was about $7.5 \mu \mathrm{gC} \mathrm{l}^{-1}$; the highest value of $57 \mu \mathrm{gC}^{-1}$ was found at $5 \mathrm{~m}$ depth (Petersen, 1978). Thalassiosira partheneia constituted the major part $(84 \%), \mu$-flagellates and the diatoms Chaetoceros and Leptocylindrus and ciliates were the other organisms reported (Petersen, 1978). About $53 \%$ of $T$. partheneia were found in colonies at the surface, whereas in deeper layers the proportion of cells within colonies increased (Elbrächter and Boje, 1978). Total particulate carbon concentration (POC), however, was $154 \mu \mathrm{gC}$ $1^{-1}$ in the upper $75 \mathrm{~m}$, with a maximum value also at $5 \mathrm{~m}$ of $222 \mu \mathrm{gC}^{-1}$ and a minimum value of $114 \mu \mathrm{gC}$ $\mathrm{l}^{-1}$ at $40 \mathrm{~m}$ depth (Lenz, unpubl.). The experimental concentrations were within the range of $\mathrm{PPC}$ and PZPC, but below the natural POC concentration.

The present study was not designed to study the feeding behaviour of copepods at low food concentrations. However, it is interesting to note that all 4 copepod species showed higher filtration rates at the lower mean food concentrations (below $10 \mu \mathrm{gC}^{-1}$ ) which is in contrast to the data reported by Frost (1975).

Frost (1972) found for Calanus pacificus that maximum filtration rate increased with increasing particle size during feeding on monospecific cultures of centric diatoms, i.e. filtration rates were size dependent. On this basis, Scrippsiella trochoidea should be taken more efficiently than Thalassiosira partheneia, which is true for the pair Temora stylifera and Centropages chierchiae. Calanoides carinatus and C. helgolandicus, however, showed higher filtration rates on $T$. partheneia at similar food concentration, despite the smaller size and senescence of the algae. S. trochoidea differs from $T$. partheneia both in size and motility. Hence, the encounter rate should be higher for the dinoflagellate. The observed difference between the 4 copepod species can be associated with the difference in their feeding behaviour: $C$. carinatus and $C$. helgolandicus are primarily filter-feeding species, whereas $T$. stylifera and $C$. chierchiae are strongly omnivorous.

As described by Elbrächter and Boje (1978), disintegration into single cells is a common phenomenon for Thalassiosira partheneia. The results shown here suggest that $T$. partheneia is a suitable food organism in older upwelled waters and in deeper layers where the colonies disintegrate due to senescence. It should 
be mentioned that the colonies of $T$. partheneia are not gelatinous. The short individual chains are held together by a thicker central thread and many twisted marginal ones (Elbrächter and Boje, 1978). Such colonies disintegrate much faster than gelatinous ones and one might expect the physiological state of the algal cells at disintegration to be still sufficiently good to serve as food for grazers. As pointed out already, the larger colonies of $T$. partheneia were not eaten by copepods of different feeding modes.

Similar experiments run with colonies of the gelatinous Phaeocystis pouchetii in the Antarctic in 1980 showed the same negative results for filter feeding copepods (Calanus propinquus, Rhincalanus gigas, Eucalanus sp.); however, copepods with a mixed and a raptorial feeding mode (Metridia gerlachei and Pareuchaeta antarctica, respectively) did feed on the colonies (Schnack, unpubl.). Feeding on P. pouchetii by different, mainly omnivorous, copepod species in the North Sea has been reported by Lebour (1922), Jones and Haq (1963) and Weise (1982). However, the $P$. pouchetii colonies used by Weise as well as by Schnack in their feeding experiments were generally much shorter than those of Thalassiosira partheneia used in the present study $(0.05$ to $1.5 \mathrm{~mm}$ compared with 1.5 to $2.0 \mathrm{~cm}$ ).

From these results one might speculate that colony building in the phytoplankton represents an adaptation to discourage grazing, particularly of those filterfeeding copepods that are characteristic of diatom blooms. Raptorial species might well be discouraged by the size of larger colonies. Possibly, the greater amount of jelly in larger colonies of gelatinous species might be the reason for their apparent unpalatability. However, the fact that a non-gelatinous species such as Thalassiosira partheneia is also not relished in colonyform would indicate that size indeed is the decisive factor. This assumption is supported by the observations of Ferguson et al. (1982) and Thompson et al. (1982) who showed that (in a lacustrine environment), smaller colonies of the gelatinous cyanophyte Microcystis were eaten by zooplankton but not the larger, older colonies. None of the copepod species were adapted to feeding on $T$. partheneia. It remains to be seen whether other animals (such as salps and euphausiids) are able to feed on the large colonies of this diatom.

Acknowledgements. This research was supported by the 'Deutsche Forschungsgemeinschaft' within the program 'Upwelling in the Sea'. Dr. M. Elbrächter provided algae cultures; he, Drs. R. J. Conover, D. Gifford, G.-A. Paffenhöfer and V. Smetacek reviewed the manuscript. I thankfully acknowledge their help.

\section{LITERATURE CITED}

Brockmann, C., Hughes, P., Tomczak, M. (1977). Data report on currents, winds and stratification in the NW African Upwelling Region during early 1975. Ber. Inst. Meeresk. Kiel 32: 1-45

Conover, R. J. (1956). Oceanography of Long Island, 1952-1954. VI. Biology of Acartia clausi and A. tonsa. Bull. Bingham oceanogr. Coll. 15: 156-233

Elbrächter, M., Boje, R. (1978). On the ecological significance of Thalassiosira partheneia in the Northwest African Upwelling Area. In: Boje, R., Tomczak, M. (eds.) Upwelling ecosystems. Springer Verlag, Berlin, p. 24-31

Ferguson, A. J. D., Thompson, J. M., Reynolds, C. S. (1982) Structure and dynamics of zooplankton communities maintained in closed systems, with special reference to the algal food supply. J. Plankton Res. 4: 523-543

Frost, B. W. (1972). Effects of size and concentration of food particles on the feeding behavior in Calanus pacificus. Limnol. Oceanogr. 17: 805-815

Frost, B. W. (1975). A threshold feeding behavior in Calanus pacificus. Limnol. Oceanogr. 20: 263-266

Jones, P. G. W., Haq, S. M. (1963). The distribution of Phaeocystis in the eastern Irish Sea. J. Cons. 28: 8-20

Lebour, M. V. (1922). The food of plankton organisms. J. mar. biol. Ass. U.K. 12: 644-677

Lenz, J. (1974). Untersuchungen zum Nahrungsgefüge im Pelagial der Kieler Bucht, der Gehalt an Phytoplankton, Zooplankton und organischem Detritus in Abhängigkeit von Wasserschichtung, Tiefe und Jahreszeit. Habilitationsschrift, Universität Kiel

Marshall, S. M., Orr, A. P. (1966). Respiration and feeding in some small copepods. J. mar. biol. Ass. U.K. 46: 523-530

Muck, P., Lampert, W. (1980). Feeding of freshwater filterfeeders at very low food concentrations: poor evidence for 'threshold feeding' and 'optimal foraging' in Daphnia longispina and Eudiaptomus gracilis. J. Plankton Res. 2: 367-379

Mullin, M. M. (1963). Some factors affecting the feeding of marine copepods of the genus Calanus. Limnol. Oceanogr. 8: $239-250$

Parsons, T. R., LeBrasseur, R. J., Fulton, J. D. (1967). Some observations on the dependence of zooplankton grazing on the cell size and concentration of phytoplankton blooms. J. oceanogr. Soc. Japan 23: 10-17

Parsons, T R., Takahashi, M., Hargrave, B. (1977). Biological oceanographic processes. Pergamon Press, Oxford

Petersen, R. (1978). Die Artenzusammensetzung der planktischen Diatomeen des westafrikanischen Auftriebsgebietes in Abhängigkeit von den hydrographischen Verhältnissen während der 'Meteor Expedition Auftrieb 75'. Diplom-Thesis, Universität Kiel

Poulet, S. A. (1978). Comparison between five coexisting species of marine copepods feeding on natural occurring particulate matter. Limnol. Oceanogr. 23: 1126-1143

Smetacek, V. (1975). Die Sukzession des Phytoplanktons in der westlichen Kieler Bucht. Ph.D. thesis, Universität Kiel

Thompson, J. M., Ferguson, A. J. D., Reynolds, C. S. (1982). Natural filtration rates of zooplankton in a closed system: the derivation of a community grazing index. J. Plankton Res. 4: $545-560$

Weise, T. (1982). Uber die Auswirkung einer Phaeocystis pouchetii-Blüte auf die dominierenden Copepodenarten des Nordsylter Wattenmeeres. Diplom-Thesis, Universität Kiel 